\title{
Aleksandra Wójcicka
}

\section{Spółka komandytowa jako podatnik CIT}

\begin{abstract}
Streszczenie
Celem artykułu jest analiza nowelizacji ustawy o podatku dochodowym od osób prawnych i włączenia do zakresu przedmiotowego tej ustawy spółek komandytowych. Jest to niewątpliwie duża reforma w funkcjonowaniu tego typu spółek osobowych. Wiąże się ze swoistym podwójnym opodatkowaniem, ponieważ następuje ono najpierw na poziomie spółki, a następnie, na poziomie wspólników. Ustawodawca kierował się chęcią optymalizacji podatkowej i uszczelnieniem systemu podatkowego, co w przypadku spółek komandytowych wydaje się powodem wątpliwym. Spółki komandytowe wybierane są bowiem najczęściej do prowadzenia tzw. biznesów rodzinnych. Konieczność dostosowywania modeli rozliczeń do nowych przepisów wiąże się z dodatkowymi kosztami dla przedsiębiorców, co może zniechęcać do prowadzenia działalności gospodarczej w ramach tego typu spółki. Czas pokaże, czy powody, którymi kierował się legislator były słuszne i czy poprawiły warunki prowadzenia biznesu w Polsce.
\end{abstract}

\section{Wstęp: cel artykułu i metoda badawcza}

Celem artykułu jest analiza sposobu prowadzenia działalności gospodarczej w postaci spółki komandytowej w obliczu zmian w opodatkowaniu tego typu spółek osobowych i objęcia ich podatkiem dochodowym od osób prawnych, na podstawie ustawy z 28.121.2020 r. o zmianie ustawy o podatku dochodowym od osób fizycznych, ustawy o podatku dochodowym od osób prawnych, ustawy o zryczałtowanym podatku dochodowym od niektórych przychodów osiąganych przez osoby fizyczne oraz niektórych innych ustaw ${ }^{1}$, która weszła w życie 1.1.2021 r.

\footnotetext{
${ }^{1}$ Ustawa z 28.11.2020 r. o zmianie ustawy o podatku dochodowym od osób fizycznych, ustawy o podatku dochodowym od osób prawnych, ustawy o zryczałtowanym podatku dochodowym od niektórych przychodów osiąganych przez osoby fizyczne oraz niektórych innych ustaw; Dz. U. poz. 2123.
} 
Zmiana w opodatkowaniu spotkała się $\mathrm{z}$ silną krytyką zarówno ze strony przedsiębiorców, jak i doktryny prawniczej². Jednym z ważniejszych czynników przesądzających o wyborze spółki komandytowej jako mechanizmu prowadzonej działalności gospodarczej było jednokrotne opodatkowanie i ograniczenie odpowiedzialności komandytariuszy. Od stycznia 2021 r. spółki komandytowe traktowane są jak podatnicy podatku CIT, co wiąże się z podwójnym opodatkowaniem. Nastąpiło tym samym zupełne przedefiniowanie modelu opodatkowania tych spółek. Przedsiębiorcy wskazywali, że cały proces zmian nastąpił zbyt szybko i mieli zbyt mało czasu na przygotowanie się do nowej rzeczywistości³ . Głos krytyczny w doktrynie prawniczej zajęli m.in. A. Mariański i Ł. Porada, którzy wskazali, że ustawodawca, mimo że nie odniósł się do tego bezpośrednio w uzasadnieniu do wprowadzonych zmian, to jednak kierował się głównie uszczelnianiem systemu podatkowego, co natomiast wydaje się w przypadku spółek komandytowych zupełnie niepotrzebne i wynika $\mathrm{z}$ błędnego przekonania, że przedsiębiorcy wybierają spółki komandytowe wyłącznie w celach optymalizacji podatkowej. Autorzy krytykowali również brak odpowiedniego vacatio legis pozwalającego na przygotowanie się przedsiębiorców do wprowadzonych zmian oraz na zbytnią rygorystyczność przepisów tam, gdzie uszczelnienia podatkowe nie są potrzebne ${ }^{4}$. Podważany jest sens prowadzenia działalności $\mathrm{w}$ tej formie w przypadku objęcia jej podatkiem dochodowym od osób prawnych. Objęcie spółek komandytowych podatkiem CIT spowodowało, że prawie 73000 polskich przedsiębiorcówwspólników jest zmuszonych do płacenia większych podatków ${ }^{5}$.

Autorka w niniejszym artykule posłużyła się metodą analizy dogmatycznej; korzystała także z narzędzi metody analizy statystycznej. Analizę dotychczasowych rozwiązań regulacyjnych oraz wprowadzonych zmian, prowadzoną na podstawie obowiązującego i nieaktualnego już ustawodawstwa oraz uzasadnień projektów ustaw, uzupełnia przegląd stanowiska doktryny prawniczej oraz wypowiedzi w materiałach internetowych, dotyczące problematyki spółki komandytowej oraz jej opodatkowania przed rokiem 2021 r.,

\footnotetext{
${ }^{2}$ Między innymi A. Kidyba w: Komentarz aktualizowany do art. 1-300 Kodeksu spótek handlowych, LEX/el. 2021, art. 102; A. Mariański, Ł. Porada, Zmiany w podatkach dochodowych w 2021 r., „, Monitor Podatkowy” 2020, nr 12, s. 17; A. Tarka, CIT od spótek komandytowych: firmy rodzinne zaskoczone, szturmuja doradców podatkowych, „Rzeczpospolita”, online: https://www.rp.pl/Podatek-dochodowy/312019912-CIT-od-spolekkomandytowych-firmy-rodzinne-zaskoczone-szturmuja-doradcow-podatkowych.html (dostęp: 27.06 .021 r.);

${ }^{3}$ A. Tarka, CIT od spółek komandytowych ..., op.cit. (dostęp: 27.6.2021 r.).

${ }^{4}$ A. Mariański, Ł. Porada, Zmiany w podatkach..., s. 17.

${ }^{5}$ SPK w Polsce analiza danych, online: https://zpp.net.pl/wp-content/uploads/2020/10/SPK-w-Polsce-analizadanych.pdf (dostęp: 24.5.2021 r.).
} 
a także dosyć nowe, nieliczne publikacje odnoszące się do zmian i objęcia spółki komandytowej podatkiem CIT.

W związku z podjętym tematem autorka stara się odpowiedzieć na następujące pytania badawcze:

1. czym jest spółka komandytowa, jakie są jej rodzaje i jakie są jej główne atrybuty,

2. w jaki sposób ukształtowana była prawna regulacja podatkowa spółek komandytowych,

3. jaki wpływ na działalność spółek komandytowych mają zmiany przepisów dotyczących podatku dochodowego od osób prawnych.

Za hipotezę badawczą autorka stawia następujące stwierdzenie: zmiany w opodatkowaniu spółek komandytowych w znacznym stopniu obciążyły wspólników tego typu spółki doprowadzając do podwójnego opodatkowania dochodów osiąganych przez wspólników, raz na poziomie spółki i drugi raz na poziomie wspólników, co może doprowadzić do zmniejszenia liczby tego typu spółek w Polsce.

\section{Spółka komandytowa jako forma prowadzenia działalności gospodarczej}

Spółka komandytowa jest uznawana za najstarszą spółkę prawa handlowego ${ }^{6}$. Jej nazwa wywodzi się od łacińskiego „commendare”, co oznacza ,zalecać”. Pierwowzór spółki oparty był o mechanizm polegający na powierzaniu kupcom towarów, bądź pieniędzy, aby to oni jako ci bardziej doświadczeni w sprzedaży, dokonywali transakcji ${ }^{7}$. Pierwsze regulacje odnoszące się do spółki komandytowej pojawiły się w krajach romańskich. W XI wiecznych Włoszech powstała umowa „accomenditaria”, którą regulowało prawo zwyczajowe, ale która dała początek kodyfikacjom np. Statutowi Bolońskiemu z 1583 r., w którym odzwierciedlono podstawowej cechy tej spółki. Już wówczas wyróżniała się tym, że jeden wspólnik wnosił aktywa, a drugi spółkę prowadził. Za początek istnienia polskiej spółki komandytowej uznaje się rok 1991, w którym przywrócono regulację o tej spółce uchylone w 1965 r. Następnie w 2000 r. uchwalono Kodeks spółek handlowych, który obowiązuje do dziś ${ }^{8}$.

Spółka komandytowa to osobowa spółka prawa handlowego. W dużej mierze jest ona oparta na konstrukcji spółki jawnej, jednak mimo to jest ona odrębną spółką prawa handlowego. Zgodnie z art. 8 \& 2 k.s.h. spółka osobowa (tak więc komandytowa również) prowadzi

\footnotetext{
${ }^{6}$ Tak m.in. J. Jacyszyn, Z rodowodu spółek, Rejent 1991, nr 4, s. 48.

${ }^{7}$ Ibidem, s. 49.

${ }^{8}$ K. Kulińska-Polak, Jaka jest historia spótki komandytowej? online: https://www.komandytowa.pl/jaka-jesthistoria-spolki-komandytowej.html (dostęp: 27.06.2021 r.).
} 
przedsiębiorstwo pod własną firmą ${ }^{9}$. Celem spółki komandytowej jest prowadzenie działalności gospodarczej; jest ona zatem przedsiębiorcą. Kwalifikowana jest jako jednostka organizacyjna nieposiadająca osobowości prawnej, której ustawa przyznaje zdolność prawną (art. $33^{1}$ k.c. $\left.{ }^{10}\right)$. Oznacza to, że spółka komandytowa może samodzielnie nabywać prawa i zaciągać zobowiązania, a także posiada zdolność sądową i procesową. Podlega wpisowi do rejestru przedsiębiorców Krajowego Rejestru Sądowego. Wpis spółki ma charakter konstytutywny i, z momentem jego dokonania, zyskuje ona podmiotowość prawną.

O specyfice spółki komandytowej przesądza występowanie w jej strukturze dwóch rodzajów wspólników: komplementariusza i komandytariusza ${ }^{11}$. To właśnie wyodrębnienie komplementariusza i komandytariusza decyduje o cesze „hybrydalności” spółki komandytowej ${ }^{12}$. Dzieje się tak dlatego, że komplementariusz odznacza się atrybutami typowymi dla wspólników spółek osobowych, to znaczy ponosi osobistą, nieograniczoną, solidarną z innymi spółkami oraz subsydiarną w stosunku do spółki odpowiedzialność za zobowiązania spółki, posiadając jednocześnie prawo reprezentowania spółki. Komandytariusz stanowi natomiast swoisty „element kapitałowy” spółki z uwagi na to, że choć ponosi on ograniczoną odpowiedzialność za zobowiązania, jednak odpowiedzialność ta jest zredukowana do wysokości tzw. sumy komandytowej ${ }^{13}$. Suma komandytowa jest górną granicą odpowiedzialności komandytariusza za zobowiązania w spółce (art. 112 k.s.h.). Może być ona różna albo taka sama dla każdego komandytariusza. Wyrażona jest wprost, w złotówkach, w umowie spółki. Suma komandytowa nie jest synonimem wkładu; wkład stanowi realne przysporzenie na rzecz spółki, a suma komandytowa ma charakter abstrakcyjny.

\footnotetext{
${ }^{9}$ Ustawa z 15.9.2000 r. Kodeks spółek handlowych; t.j.: Dz. U. z 2020 r., poz. 1526, 2320, ze zm.; dalej jako: „k.s.h.”.

${ }^{10}$ Ustawa z 23.4.1964 r. Kodeks cywilny, t.j. Dz. U. z 2020 r., poz. 1740, 2320; dalej jako „k.c.”

${ }^{11}$ Za niedopuszczalne uznaje się łączenie statusu obu kategorii wspólników - tak m.in. J. Szwaja, I. Mika w: S. Sołtysiński, A. Szajkowski, A. Szumański, Kodeks spółek handlowych. Komentarz. T. 1, Wyd. 3, Warszawa 2012, Legalis - do art. 102; A. Kidyba, Status prawny komandytariusza, Bydgoszcz 2000, s. 21; idem, w: Komentarz aktualizowany do art. 1-300 Kodeksu spótek handlowych, LEX/el. 2021 - do art. 102; P. Pinior w: J. Strzępka (red.), Kodeks spótek handlowych. Komentarz. wyd. 7, Warszawa 2015, Legalis - do art. 102; J. P. Naworski, w: K. Strzelczyk, Kodeks spótek handlowych. Komentarz. Tytut I. Przepisy ogólne. Tytuł II. Spótki osobowe, red. R. Potrzeszcz, T. Siemiątkowski, Warszawa 2011, LEX/el - do art. 102; M. Rodzynkiewicz, Kodeks spótek handlowych. Komentarz, wyd. VII, Warszawa 2018, Legalis - do art. 102; T. Szczurowski, w: Kodeks spótek handlowych. Komentarz, red. Z. Jara, Warszawa 2020, wyd. 3, Legalis - do art. 102 i przywołana tam M. Tarska, Zakres swobody umów w spółkach handlowych, Warszawa 2012, s. 315. Odmiennie np. W. Górecki, A. Kappes w: Prawo spółek handlowych. Tom 2A. System Prawa Handlowego, red. A. Szumański, Warszawa 2019, wyd. 3, s. 524.

${ }^{12} \mathrm{~W}$ doktrynie przeważa słuszny pogląd uznający spółkę komandytową za odrębny od spółki jawnej typ spółki osobowej - tak m.in. J. P. Naworski, w: Kodeks...- do art. 102. Odmiennie A. Kidyba w: Komentarz aktualizowany... - do art. 102; A. Kappes, Spółka komandytowa, Warszawa 1999, s. 12; A. Kappes, Spółka komandytowa, red. A. Kidyba, Warszawa 2014, s. 22 i n.

${ }^{13}$ Tak T. Szczurowski, w: Kodeks... - do art. 102
} 
Tylko jeżeli egzekucja wobec spółki stanie się bezskuteczna wierzyciele mogą sięgnąć do majątku osobistego komandytariusza, jednak jedynie do kwoty sumy komandytowej ${ }^{14}$. Odpowiedzialność komandytariusza jest uzależniona od wkładu wnoszonego do spółki, ponieważ jeśli komandytariusz go wniesie to przestaje ponosić odpowiedzialność do granicy jego wartości. Natomiast jeśli wkład nie przewyższa sumy komandytowej, to wspólnik odpowiada do wysokości różnicy między sumą komandytową a wniesionym wkładem ${ }^{15}$.

Za osobowym charakterem spółki komandytowej przemawia przede wszystkim brak kapitału zakładowego i ponoszenie przez wspólników odpowiedzialności za zobowiązania spółki, a nadto, nieposiadanie przez spółkę osobowości prawnej, a w konsekwencji brak organów w spółce i odesłanie w zakresie nieuregulowanym do przepisów o spółce jawnej ${ }^{16}$.

Wyróżnia się kilka wariantów funkcjonowania spółek komandytowych. Wedle różnych kryteriów, można je podzielić na spółki zawierane w sposób tradycyjny, czyli poprzez umowę wspólników oraz te zawierane przez system teleinformatyczny (S24). Inny podział, bardziej interesujący z punktu widzenia opodatkowania spółki, jest zależny od sytuacji czy rodzaju wspólników w danej spółce komandytowej.

Każda spółka komandytowa to taka, w której komplementariusz odpowiada jak jest wspólnik spółki jawnej i ponosi pełną odpowiedzialność za zobowiązania spółki, a komandytariusz to wspólnik, który odpowiada ograniczenie do wysokości sumy komandytowej. Jednak poprzez wprowadzanie różnego typu wspólników do spółki (nie ma ograniczeń podmiotowych wobec uzyskania statusu komplementariusza i komandytariusza, wobec czego mogą nimi być osoby fizyczne, osoby prawne i jednostki organizacyjne pozbawione osobowości prawnej, wyposażone $\mathrm{w}$ zdolność prawną) mogą powstać różne warianty funkcjonowania spółki osobowej ${ }^{17}$. Swoboda nie jest oczywiście nieograniczona, bowiem postanowienia umowy nie mogą być sprzeczne z ustawą, naturą spółki komandytowej oraz z zasadami współżycia społecznego.

W praktyce funkcjonowania spółki komandytowej wykształciły się różne warianty jej organizacji i funkcjonowania. Powody, dla których do tego doszło, to między innymi

\footnotetext{
${ }^{14}$ Por. A. Kidyba w: Komentarz aktualizowany... - do art. 102. Autor słusznie podkreśla, że odpowiedzialność subsydiarna nie wystąpi jednak, gdy chodzi o odpowiedzialność za zaległości podatkowe spółki, gdyż zgodnie z art. 115 § 1 ustawy z 29.87.1997 r. Ordynacja podatkowa odpowiedzialność ta jest pierwszorzędna. Zob. także A. Kappes, Spótka..., s. 208 i n.

${ }^{15}$ A. Kidyba, Prawo handlowe, wyd. 22, Warszawa 2020, s. 329-333.

${ }^{16}$ K. Grzebiela, Spótka komandytowa jako optymalna forma prowadzenia działalności gospodarczej, „Security, Economy \& Law", 2018, nr 2, s. 53-54.

17 K. Wielgus, Zarys konstrukcji spółki komandytowej, w której komplementariuszem jest osoba prawna, „Internetowy Przegląd Prawniczy TBSP UJ” 2018, s. 152 określa je „podtypami spółki komandytowej”.
} 
szukanie sposobu na ograniczenie odpowiedzialności wspólników, chęć optymalizacji podatkowej, czy uzyskanie elastyczności działania spółki ${ }^{18}$.

Podtyp mieszany spółki komandytowej to taki, w której oprócz osoby fizycznej jako wspólnika, pojawia się spółka kapitałowa. Przykładowo do podtypu mieszanego zaliczana jest spółka z ograniczoną odpowiedzialnością spółka komandytowa ${ }^{19}$. Jako że ustawodawca nie wprowadził ograniczenia co do tego kto może być wspólnikiem, taki rodzaj spółki komandytowej jest dopuszczalny $\mathrm{w}$ prawie polskim i często wykorzystywany przez przedsiębiorców.

Wyróżnia się także trzy konfiguracje spółki komandytowej w zależności od uprawnień przysługujących jej wspólników. W modelu klasycznym kodeksowym komandytariusz nie posiada uprawnienia do kontrolowania spółki. Natomiast model dynamiczny oparty jest na dużym zaangażowaniu komandytariusza w sprawy spółki, w którym korzysta się z art. 117 k.s.h stanowiącego, że komandytariusz może reprezentować spółkę jako pełnomocnik, a także z art. 121 k.s.h., według którego umowa spółki może przewidywać uprawnienie komandytariusza do prowadzenia spraw spółki. Między tymi dwoma kategoriami można wyróżnić model pośredni, w którym komandytariusz co prawda nie posiada prawa do kontroli, ale może on reprezentować i prowadzić sprawy spółki na podstawie pełnomocnictwa bądź prokury ${ }^{20}$.

Odrębnie ujmuje się sp. z o.o. sp. k. Po pierwsze może ona występować jako tzw. spółka właściwa, czyli taka, w której wspólnicy spółki z o.o., która posiada status komplementariusza, są jednocześnie wspólnikami spółki komandytowej. W spółce niewłaściwej natomiast nie każdy wspólnik sp. z o.o. jest jednocześnie wspólnikiem w spółce komandytowej. Spółka jednolita komandytowa to taka, w której wszystkie udziały spółki z o.o. są przenoszone do spółki komandytowej i z uwagi na to spółka komandytowa jest jedynym wspólnikiem spółki z o.o. jako komplementariusza. W Niemczech wyróżniona została jeszcze inna forma spółki komandytowej, a mianowicie taka, w której spółka komandytowa jest zawiązywana przez

\footnotetext{
${ }^{18}$ Ibidem, s. 151

${ }^{19}$ Dalej jako sp. z o.o. sp. k. Por. na ten temat zwłaszcza A. Kidyba, Zasady działania spółki komandytowej z udziałem spótek handlowych jako komplementariuszy, Rejent, 2000, nr 4, s. 26-42; E.J. Krześniak, Spótka komandytowa z udziałem spótki z ograniczona odpowiedzialnością, Rejent, 2000, nr 9, s. 28 i n.; M.R. Podświadek, Spółka z ograniczoną odpowiedzialnościa jako komplementariusz w spótce komandytowej, PPH 2001, nr 10, s. 4; J. Jerzmanowski, Praktyczne aspekty tworzenia i organizacji spółek komandytowych z udziałem spótek z o.o. jako komplementariuszy, PPH 2010, nr 12, s. 40 i n.; zob. również A. Kappes, Odpowiedzialność członków zarządu spółki z o.o. będącej komplementariuszem w spółce komandytowej za zobowiąania tej spółki, PPH 2017, nr 12, s. 5 i n.

${ }^{20}$ Por. A. Kidyba, Handlowe spółki osobowe, Warszawa 2010, s. 244 i n.; K. Wielgus, Zarys..., s. 156.
} 
jednoosobową spółkę z o.o., której jedyny wspólnik jest komandytariuszem spółki komandytowej ${ }^{21}$.

Z danych GUS wynika, że w 2019 roku w Polsce zarejestrowanych było 40,6 tys. spółek komandytowych, co stawia tego rodzaju spółki na czele w zestawieniu liczebności spółek osobowych prawa handlowego w Polsce ${ }^{22}$. Wydaje się, że największy wpływ na taki stan rzeczy ma hybrydowa natura spółki komandytowej.

W mniej więcej 92\% funkcjonujących w Polsce spółek komandytowych wspólnicy to osoby fizyczne zamieszkałe w Polsce. Wskazuje się, że tylko 1\% wszystkich spółek komandytowych w Polsce (czyli 439) posiada zagranicznych wspólników, dlatego obawy odnoszące się do przenoszenia nieopodatkowanego zysku przez spółki za granicę nie są uzasadnione. Dane pokazują, że najczęściej prowadzonymi działalnościami gospodarczymi przez tego rodzaju spółki są: przetwórstwo przemysłowe, budownictwo, handel hurtowy i detaliczny, naprawa pojazdów mechanicznych, transport i gospodarka magazynowa, a także zakwaterowanie i usługi gastronomiczne oraz obsługa rynku nieruchomości. Należy wskazać, że bardzo często ta forma działalności gospodarczej wybierana jest do prowadzenia interesów rodzinnych ${ }^{23}$.

\section{Dotychczasowy sposób opodatkowania w spółkach komandytowych}

Do końca roku 2020 spółka komandytowa nie była objęta podatkiem dochodowym od osób prawnych. Taką sytuację określa się mianem transparentności podatkowej24, która ma miejsce wówczas, gdy sama spółka nie jest zobowiązana do odprowadzania podatku od jej dochodów. Obowiązek podatkowy powstawał więc na poziomie wspólników, którzy płacili podatek od dochodów w spółce proporcjonalny do udziału w zysku. Należy podkreślić, że status wspólnika w żaden sposób nie oddziaływał na opodatkowanie. W konsekwencji zarówno komplementariusze jak i komandytariusze w spółce płacili podatek dochodowy od osób fizycznych albo podatek dochodowy od osób prawnych na takich samych zasadach. Do czasu nowelizacji przepisów prawa podatkowego z 2020 r. wspólnik spółki komandytowej,

\footnotetext{
${ }^{21}$ Ibidem, s. 158-159

${ }^{22}$ Zmiany strukturalne grup podmiotów gospodarki narodowej w rejestrze REGON, 2019 r., Raport GUS, s. 14 https://stat.gov.pl/obszary-tematyczne/podmioty-gospodarcze-wyniki-finansowe/zmiany-strukturalne-gruppodmiotow/zmiany-strukturalne-grup-podmiotow-gospodarki-narodowej-w-rejestrze-regon-2019-r-, 1,24.html (dostęp 30.05.2021).

${ }^{23}$ Ibidem, ss. 118-135.

${ }^{24}$ Por. A. Kidyba w: Komentarz aktualizowany... - do art. 102.
} 
na potrzeby rozliczania podatku dochodowego, mógł odliczać od dochodu uzyskanego w jednej spółce komandytowej stratę ponoszoną w innej spółce komandytowej lub stratę, która powstała w prowadzonej przez wspólnika jako osoby fizycznej jednoosobowej działalności gospodarczej. Miało więc miejsce kalkulowanie zysków i strat wspólnika ${ }^{25}$.

Rodzaj płaconego podatku w spółce komandytowej zależał od statusu podatkowego wspólnika. Wspólnicy - osoby fizyczne mieli możliwość wyboru sposobu opodatkowania. Mogli wybrać podatek liniowy w wysokości 19\% niezależnie od wysokości dochodu, a także mogli płacić go na zasadach ogólnych, czyli w skali podatkowej. Poniższa tabela prezentuje to, ile - w przybliżeniu - dochodu, który przypadał na wspólnika, trafiało do niego rzeczywiście w zależności od wyboru sposobu opodatkowania.

\begin{tabular}{|l|l|}
\hline \multicolumn{1}{|c|}{ Sposób opodatkowania } & \multicolumn{1}{c|}{ Co otrzymuje wspólnik } \\
\hline $19 \%$ podatek liniowy & $\begin{array}{l}81 \% \text { przypadającego na wspólnika dochodu } \\
\text { spółki }\end{array}$ \\
\hline $\begin{array}{l}18 \% \text { podatek dochodowy do } 85.528,00 \mathrm{zl} \\
\text { dochodu w danym roku }\end{array}$ & $\begin{array}{l}82 \% \text { przypadającego na wspólnika dochodu } \\
\text { spółki }\end{array}$ \\
\hline $\begin{array}{l}32 \% \text { podatek dochodowy powyżej } \\
85.529,00 \mathrm{zł}\end{array}$ & $\begin{array}{l}68 \% \text { przypadającego na wspólnika dochodu } \\
\text { spółki }\end{array}$ \\
\hline
\end{tabular}

Opracowano na podstawie: M. Jędrzejczyk, Konsekwencje prowadzenia działalności gospodarczej w ramach spótki komandytowej $w$ podatkach dochodowych w: Prawo administracyjne $i$ gospodarze a sytuacja przedsiębiorcy na rynku polskim, red. M. Górska, K. Zapała, Kielce 2014, s. 77-78.

Dotychczas bardzo popularne było wprowadzanie do spółek komandytowych jako wspólników spółek z ograniczoną odpowiedzialnością. Najczęściej spółka kapitałowa występowała w spółkach komandytowych jako komplementariusz. Ta forma prowadzenia działalności gospodarczej jest dość często wykorzystywana za granicą np. w Niemczech. Powodów, dla których przedsiębiorcy wprowadzają spółki kapitałowe do spółek komandytowych jest kilka. Jednym z ważniejszych jest możliwość łączenia cech spółek osobowych i spółek kapitałowych, by w konsekwencji uzyskać korzystną formę prowadzenia działalności gospodarczej. Innym jest możliwość ograniczenia odpowiedzialności wspólników będących osobami fizycznymi. Jeśli bowiem do spółki wprowadzono spółkę z ograniczoną odpowiedzialnością jako jedynego wspólnika - komplementariusza to ta spółka będzie ponosiła pełną odpowiedzialność za zobowiązania spółki. Natomiast komandytariusze jako osoby

\footnotetext{
${ }^{25}$ A. Bieńkowska, P. Furmanek, A. Kardyś, Przegląd zmian podatkowych 2021, Warszawa 2021, s. 4.
} 
fizyczne w takiej spółce będą ponosili, zgodnie z kodeksowymi zasadami odpowiedzialności, odpowiedzialność za zobowiązania spółki do wysokości sumy komandytowej pomniejszonej o wartość wniesionego wkładu ${ }^{26}$. Spółka z ograniczoną odpowiedzialnością jest podatnikiem CIT, tak więc dochód, jaki otrzymują wspólnicy wchodzący w jej skład, podlega podwójnemu opodatkowaniu: raz na etapie spółki, a kolejny raz poprzez opodatkowanie dochodów wspólników.

Podsumowując, konstrukcja spółki z o.o. spółki komandytowej była dotychczas bardzo korzystna dla wspólników będących osobami fizycznymi, gdyż mogli oni w ten sposób zwolnić się od pełnej odpowiedzialności za zobowiązania i jednocześnie uniknąć podwójnego opodatkowania $^{27}$. Często wykorzystywaną praktyką było zawiązywanie spółek z ograniczoną odpowiedzialnością z niskim kapitałem zakładowym tak, by ryzyko jakie ponosi ta spółka jako komplementariusz było jak najmniejsze.

\section{Opodatkowanie spółki komandytowej po 1.1.2021 r.}

Jedną $\mathrm{z}$ większych zmian $\mathrm{w}$ ustawie o podatku dochodowym od osób prawnych ${ }^{28}$ było dodanie do art. 1 ust. 3 ustawy, określającego zakres przedmiotowy regulacji, spółek komandytowych oraz spółek jawnych, których wspólnikami nie są wyłącznie osoby fizyczne i w przypadku których tożsamość podlegających opodatkowaniu, nie jest ujawniana. Sam zabieg takiego włączenia w zakres regulacji może wydawać się wewnętrznie sprzeczny, skoro ustawa reguluje podatek „od osób prawnych”, a ani spółka komandytowa, ani spółka jawna osobami prawnymi nie są. Zmiany tej obawiano się już od dawna; właściwie od momentu objęcia podatkiem CIT spółek komandytowo-akcyjnych.

Projektodawca zmian ustawowych uznał, że za wprowadzeniem omawianych zmian przemawiają:

- uszczelnienie systemu podatku dochodowego od osób prawnych,

- pełniejsza realizacja zasady sprawiedliwości podatkowej i powszechności opodatkowania,

- usuwanie niepożądanych działań optymalizacyjnych,

26 M. Piotrowska, Odpowiedzialność cywilna komplementariusza będącego spótka z ograniczona odpowiedzialnościa i członków jej zarządu w spótce komandytowej-zagadnienia wybrane, „Wrocławskie Studia Erazmiańskie. Zeszyty Prawnicze" 2009, nr 2, s. 220-221.

27 A. Stolarski, Podatkowe kryteria wyboru spótki komandytowej jako formy prowadzenia działalności gospodarczej, „Studia Ekonomiczne. Zeszyty Naukowe Uniwersytetu Ekonomicznego w Katowicach”, 2018, nr 363, s. 91.

${ }^{28}$ Ustawa z 15.2.1992 r. o podatku dochodowym od osób prawnych, t.j.: Dz. U. nr 21 poz. 86, ze zm., dalej jako „u.p.d.o.p”. 
- efektywniejsza realizacja polityki gospodarczej i społecznej poprzez redystrybuowanie środków publicznych uzyskanych z podatku dochodowego ${ }^{29}$.

Opodatkowanie na poziomie spółki komandytowej przedstawia się w taki sposób, że jej dochód podlega 19\% stawce podatkowej, jednak u.p.d.o.p. przewiduje dla tzw. małych podatników obniżoną 9\% stawkę, ale tylko w odniesieniu do dochodów innych niż zysk kapitałowy, czyli innych niż dochód z odpłatnego zbycia papierów wartościowych oraz pochodnych instrumentów finansowych, zbycia udziałów akcji itp. Mały podatnik to taki, którego przychody ze sprzedaży wraz z VAT w danym roku podatkowym nie przekroczyły równowartości $2 \mathrm{mln}$ euro przeliczanej. Równowartość ta przeliczana jest na podstawie średniego kursu euro na polski złoty.

Jeśli chodzi o opodatkowanie na poziomie wspólników to jest ono zależne od statusu wspólnika. Dochody wspólników z tytułu udziału w zyskach spółki komandytowej są klasyfikowane tak jak dochody z udziale w zysku osób prawnych. Komplementariusz będący osobą prawną co do zasady będzie płacił 19\% podatek dochodowy od osób prawnych. Ustawodawca przewidział jednak pewną ulgę, polegającej na możliwości „zaliczenia” na poczet zryczałtowanego podatku dochodowego od uzyskanych przychodów, kwoty odpowiadającej iloczynowi procentowego udziału w zysku i należnego podatku, z zastrzeżeniem jednak, że kwota ta nie może być wyższa niż podatek od przychodów $\mathrm{z}$ dywidend i innych przychodów $\mathrm{z}$ tytułu udziału w zyskach osób prawnych mających siedzibę lub zarząd na terytorium Rzeczpospolitej Polskiej.

Podobne zasady mają zastosowanie do komplementariusza - osoby fizycznej, z tym że odprowadza on podatek od osób fizycznych. Dochód ten kwalifikowany jest jako przychód z kapitałów pieniężnych. Dochody komandytariusza również będą traktowane jako dochód $\mathrm{z}$ udziału $\mathrm{w}$ zyskach osób prawnych. Istotne jest natomiast to, że w przypadku komandytariusza nie ma możliwości pomniejszenia zryczałtowanego podatku dochodowego o podatek zapłacony przez spółkę. Tak więc na mocy wprowadzonej nowelizacji, komandytariusze odczują podwójne opodatkowanie. Najpierw bowiem spółka będzie odprowadzała podatek od swojego dochodu, a następnie podatek odprowadzać będzie komandytariusz od wypłaconego zysku, czyli od uzyskanego dochodu.

Ustawodawca przewidział pewne zwolnienie podatkowe od części przychodów komandytariusza. Obwarowane jest to natomiast szeregiem warunków.

\footnotetext{
${ }^{29}$ Uzasadnienie projektu z 15.9.2020 r., https://legislacja.rcl.gov.pl/docs//2/12338256/12719141/12719142/dokument464550.pdf (dostęp 28.05.2021 r.), dalej jako ,projekt”.
} 
Po pierwsze zwolnienie od podatku dochodowego możliwe jest do tylko do kwoty stanowiącej 50\% przychodów, które komandytariusz uzyskał jako udział w zysku spółki komandytowej.

Po drugie wysokość zwolnienia podatkowego nie może być wyższa niż 60,000 zł w danym roku podatkowym. Zwolnienie to stosuje się odrębnie dla każdej spółki, w której komandytariusz jest wspólnikiem. Skorzystanie ze zwolnienia nie będzie jednak możliwe, jeśli będzie widoczne to, że spółka komandytowa została zawiązana w celu optymalizacji podatkowej. Artykuły 21 ust. 40 ustawy o podatku dochodowym od osób fizycznych ${ }^{30}$ oraz art. 22 ust. 4 u.p.d.o.p. wymieniają szczegółowo sytuacje, w których komandytariusz nie będzie mógł skorzystać ze zwolnienia, takie sytuacje jak: posiadanie przez komandytariusza bezpośrednio lub pośrednio co najmniej 5\% udziałów lub akcji w spółkach posiadających osobowość prawną lub spółkach kapitałowych w organizacji, które to spółki posiadają status komplementariuszy w spółce komandytowej; posiadanie statusu członka zarządu w tych spółkach; bycie przez komandytariusza podmiotem powiązanym z członkiem zarządu lub wspólnikiem takiej spółki ${ }^{31}$.

Powyższe regulacje weszły w życie 1.1.2021 r., jednak spółki komandytowe miały możliwość odroczenia stosowania zmienionych przepisów do 1.5.2021 r. Wiele spółek skorzystało z możliwości przesunięcia tego terminu, co pokazuje, że zmiana ta nie była przez przedsiębiorców wyczekiwana.

Nowa regulacja budzi zastrzeżenia. Dopiero interpretacje podatkowe, które pojawiły się po nowelizacji ustawy, rozwiały niektóre wątpliwości przedsiębiorców. Wiadomo, że zysk, który został wypracowany przed wejściem nowego sposobu opodatkowania, nie podlega opodatkowaniu, nawet wówczas, gdy zostanie on wypłacony wspólnikom już po uzyskaniu statusu podatnika CIT przez spółkę komandytową. Zysk wypracowany po uzyskaniu tego statusu zostanie już obciążony podatkiem. Jak wskazują wydane interpretacje, w kontekście pomniejszania podatku komandytariuszy, będzie to możliwe dopiero na koniec roku, gdy znana już będzie całkowita wysokość podatku dochodowego płaconego na poziomie spółki. W konsekwencji wspólnicy - komandytariusze będą nadpłacać podatek i odzyskiwać nadwyżkę po zakończonym roku ${ }^{32}$.

\footnotetext{
${ }^{30}$ Ustawa z 26.7.1991 r. o podatku dochodowym od osób fizycznych, t.j.: Dz. U. 2021, poz. 1128, dalej jako: ,u.o.p.d.o.f.".

${ }_{31}^{31}$ A. Bieńkowska, P. Furmanek, A. Kardyś, Przeglad zmian..., s. 5-7.

32 Wydane interpretacje podsumowuje P. Wojtasik, Nowe życie spótek komandytowych, „Rzeczpospolita”, wydanie nr 11953, Legalis 2021.
} 
Nowelizacja zmieniła także kwestie podlegania wspólników spółek komandytowych pod tzw. daninę solidarnościową, czyli świadczenie pieniężne niezależne od opodatkowania, które wprowadzone zostało ustawą o Funduszu Solidarnościowym ${ }^{33}$ i który dotyczy osób fizycznych uzyskujących dochód (czyli przychód pomniejszony o koszty) podlegający opodatkowaniu podatkiem PIT $^{34}$. Obowiązek płacenia tego rodzaju świadczenia pieniężnego mają podmioty, których dochody przekraczają 1000000 zł rocznie. Wówczas od dochodu przekraczającego tą kwotę, istnieje obowiązek odprowadzania 4\% daniny. Przy wyliczaniu nadwyżki pod uwagę bierze się: opodatkowane dochody z pracy, działalności gospodarczej, renty, z praw autorskich; dochody z zysków kapitałowych, dochody opodatkowane podatkiem liniowym, dochody z zagranicznej spółki kontrolowanej. Wliczeniu nie podlegają natomiast: przychody opodatkowane podatkiem zryczałtowanym np. z dywidend, odsetek; dochody z odpłatnego zbycia nieruchomości; dochody zagraniczne zwolnione od podatku; przychody opodatkowane ryczałtem od przychodów ewidencjonowane i tych które mają formę karty podatkowej. Do czasu wprowadzenia zmian w opodatkowaniu spółek komandytowych, dochody wspólników traktowane były jako pochodzące z pozarolniczej działalności gospodarczej i zgodnie z art. 30h u.o.p.d.o.f. podlegały pod daninę solidarnościową. Zmiana klasyfikacji przychodów wspólnika spółki komandytowej jako przychód z zysków kapitałowych powoduje, że nie są oni zobowiązani do odprowadzania tego świadczenia pieniężnego ${ }^{35}$.

\section{Podsumowanie}

Zmiana w sposobie opodatkowaniu spółek komandytowych to niewątpliwie rewolucyjne rozwiązanie. Ustawodawca kierował się z pewnością słusznymi z punktu widzenia gospodarki narodowej ideami, jak uszczelnienie systemu podatkowego, co nie zmienia faktu, że zmiany wiążą się z wieloma trudnościami i dodatkowymi kosztami dla przedsiębiorców. Zmuszeni są oni bowiem dostosować modele rozliczeń do nowej formy opodatkowania. Biorąc pod uwagę duże obciążenie finansowe, przede wszystkim komandytariuszy, możliwym scenariuszem jest przekształcanie spółek komandytowych w spółki jawne, partnerskie lub spółki z o.o. Przyszłość pokaże, czy dotychczas dość popularna forma prowadzenia

\footnotetext{
${ }^{33}$ Ustawa z 23.10.2018 r. o Funduszu Solidarnościowym, t.j.: Dz. U. 2020, poz. 1787.

${ }^{34}$ Ministerstwo Finansów, Danina solidarnościowa - objaśnienia podatkowe Ministerstwa Finansów z dnia 28

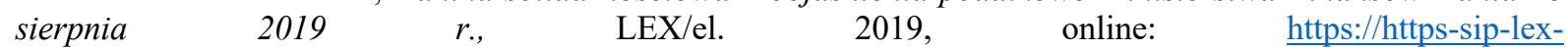
pl.pulpit.uksw.edu.pl/\#/publication/151355320?pit=2021-06-27, (dostęp: 27.06.2021 r.)

${ }^{35}$ A. Bieńkowska, P. Furmanek, A. Kardyś, Przegląd zmian..., s. 10.
} 
działalności gospodarczej, szczególnie dla rodzinnych interesów, dalej będzie kontynuowana. Być może przedsiębiorcy będą szukać innych, optymalnych rozwiązań dla swoich interesów. Ustawodawca nowelizując przepisy odnoszące się do podmiotów gospodarczych powinien dążyć do stwarzania możliwie najlepszych warunków do prowadzenia biznesu. W przypadku zmiany w opodatkowaniu spółek komandytowych na obecnym etapie, tj. pół roku po wejściu w życie przepisów, ciężko odnaleźć urzeczywistnienie pozytywów, na które wskazywał legislator w projekcie zmian. Pojawiają się opinie, wedle których, zmiana opodatkowania spowoduje obniżenie konkurencyjności polskich spółek komandytowych w porównaniu do przedsiębiorców zagranicznych prowadzących działalność w tej formie, z uwagi na wzrost opodatkowania dla wspólników ${ }^{36}$.

Summary
Limited Partnership as a CIT taxpayer
The aim of article is to analyze the amendment to the Act on Corporate Income Tax
and the inclusion of limited partnership into the scope of the act. This is undoubtedly a
major reform in the functioning of this type of partnerships. It is connected with the
necessity of experiencing double taxation, because it takes place first at the level of the
company and then at the level of the shareholders. The legislator was guided by the
wish to optimize tax and to tighten the tax system, which in the case of limited
partnerships seems to be quite a dubious reason for such a large amendment. Limited
partnerships are most often chosen to run family businesses. The necessity to adjust the
settlement models to the new regulations involves additional costs for entrepreneurs,
which may discourage from doing business in this form. Time will show whether the
reasons the legislator was guided by were right and whether they improved the
conditions for doing business in Poland.

${ }^{36}$ SPK w Polsce analiza danych, online: https://zpp.net.pl/wp-content/uploads/2020/10/SPK-w-Polsce-analizadanych.pdf (dostęp: 27.06.2021 r.). 


\section{Aleksandra Wójcicka}

Studentka IV roku prawa na Wydziale Prawa i Administracji Uniwersytetu Kardynała Stefana Wyszyńskiego w Warszawie. Uczestniczka seminarium z prawa handlowego. Zainteresowania naukowe Autorki związane są z prawem spółek, umów i transakcji handlowych. Doświadczenie zawodowe w obszarze projektów restrukturyzacyjnych i przekształceń spółek prawa handlowego zdobywa w kancelarii DJM.

\section{Bibliografia}

1. Bieńkowska A., Furmanek P., Kardyś A., Przegląd zmian podatkowych 2021, Warszawa 2021.

2. Górecki W., Kappes A., w: Prawo spótek handlowych. Tom 2A. System Prawa Handlowego, red. Szumański A., Warszawa 2019, wyd. 3.

3. Grzebiela K., Spótka komandytowa jako optymalna forma prowadzenia działalności gospodarczej, „Security, Economy \& Law”, 2018, nr 2.

4. Jacyszyn J., Z rodowodu spólek, Rejent 1991, nr 4.

5. Jerzmanowski J., Praktyczne aspekty tworzenia i organizacji spółek komandytowych z udziałem spótek z o.o. jako komplementariuszy, PPH 2010, nr 12.

6. Kappes A., Spótka komandytowa, Warszawa 1999.

7. Kappes A., Spótka komandytowa, red. Kidyba A., Warszawa 2014.

8. Kappes A., Odpowiedzialność członków zarząu spótki $z$ o.o. będacej komplementariuszem w spółce komandytowej za zobowiąania tej spótki, PPH 2017, nr 12.

9. Kidyba A., Status prawny komandytariusza, Bydgoszcz 2000.

10. Kidyba A., Handlowe spótki osobowe, Warszawa 2010.

11. Kidyba A., Prawo handlowe, wyd. 22, Warszawa 2020.

12. Kidyba A., Komentarz aktualizowany do art. 1-300 Kodeksu spółek handlowych, LEX/el. 2021.

13. Kidyba A., Zasady działania spótki komandytowej z udziałem spółek handlowych jako komplementariuszy, Rejent, 2000, nr 4.

14. Krześniak E.J., Spółka komandytowa $z$ udziałem spółki $z$ ograniczona odpowiedzialnościa, Rejent, 2000, nr 9.

15. Kulińska-Polak K., Jaka jest historia spółki komandytowej? online: https://www.komandytowa.pl/jaka-jest-historia-spolki-komandytowej.html (dostęp: 27.06.2021 r.).

16. Mariański A., Porada Ł., Zmiany w podatkach dochodowych w 2021 r., ,, Monitor Podatkowy" 2020, nr 12.

17. Naworski J. P., w: Kodeks spółek handlowych. Komentarz. Tytuł I. Przepisy ogólne. Tytuł II. Spótki osobowe, Potrzeszcz R., Siemiątkowski T. (red.), Warszawa 2011, LEX/el

18. Pinior P., w: Kodeks spótek handlowych. Komentarz, red. Strzępka J., wyd. 7, Warszawa 2015, Legalis.

19. Piotrowska M., Odpowiedzialność cywilna komplementariusza będacego spółka z ograniczona odpowiedzialnościq $i$ członków jej zarządu w spółce komandytowej zagadnienia wybrane, „Wrocławskie Studia Erazmiańskie. Zeszyty Prawnicze” 2009, $\mathrm{nr} 2$. 
20. Podświadek M.R., Spółka z ograniczona odpowiedzialnościa jako komplementariusz w spółce komandytowej, PPH 2001, nr 10.

21. Rodzynkiewicz M., Kodeks spółek handlowych. Komentarz, wyd. VII, Warszawa 2018, Legalis.

22. Stolarski A., Podatkowe kryteria wyboru spółki komandytowej jako formy prowadzenia działalności gospodarczej, „Studia Ekonomiczne. Zeszyty Naukowe Uniwersytetu Ekonomicznego w Katowicach", 2018, nr 363.

23. Szczurowski T., w: Kodeks spótek handlowych. Komentarz, red. Jara Z., Warszawa 2020, wyd. 3, Legalis.

24. Szwaja J., Mika I., w: S. Sołtysiński, A. Szajkowski, A. Szumański, Kodeks spółek handlowych. Komentarz. T. 1, Wyd. 3, Warszawa 2012, Legalis.

25. Tarska M., Zakres swobody umów w spótkach handlowych, Warszawa 2012.

26. Wielgus K., Zarys konstrukcji spótki komandytowej, w której komplementariuszem jest osoba prawna, „Internetowy Przeglad Prawniczy TBSP UJ” 2018.

27. Wojtasik P., Nowe życie spótek komandytowych, „Rzeczpospolita”, wydanie nr 11953, Legalis 2021.

28. Tarka A., CIT od spółek komandytowych: firmy rodzinne zaskoczone, szturmuja doradców podatkowych, „Rzeczpospolita”, online: https://www.rp.pl/Podatekdochodowy/312019912-CIT-od-spolek-komandytowych-firmy-rodzinne-zaskoczoneszturmuja-doradcow-podatkowych.html (dostęp: 27.06.021 r.).

29. SPK $w$ Polsce analiza danych, online: https://zpp.net.pl/wpcontent/uploads/2020/10/SPK-w-Polsce-analiza-danych.pdf (dostęp: 24.5.2021 r.).

30. Zmiany strukturalne grup podmiotów gospodarki narodowej w rejestrze REGON, 2019 $r$., Raport GUS, s. 14 https://stat.gov.pl/obszary-tematyczne/podmioty-gospodarczewyniki-finansowe/zmiany-strukturalne-grup-podmiotow/zmiany-strukturalne-gruppodmiotow-gospodarki-narodowej-w-rejestrze-regon-2019-r-,1,24.html (dostęp 30.05.2021).

31. Uzasadnienie projektu $\quad \mathrm{z} \quad 15.9 .2020 \quad$ r., https://legislacja.rcl.gov.pl/docs//2/12338256/12719141/12719142/dokument464550.p df (dostęp 28.05.2021 r.).

32. Ministerstwo Finansów, Danina solidarnościowa - objaśnienia podatkowe Ministerstwa Finansów z dnia 28 sierpnia 2019 r., LEX/el. 2019, online: https://httpssip-lex-pl.pulpit.uksw.edu.pl/\#/publication/151355320?pit=2021-06-27, ， (dostęp: 27.06.2021 r.). 